\title{
Reduced Fungicide Applications and Host Resistance for Managing Three Diseases in Pumpkin Grown on a No-Till Cover Crop
}

\author{
Kathryne L. Everts, University of Maryland College Park, Salisbury 21801 and University of Delaware, George- \\ town 19947
}

\begin{abstract}
Everts, K. L., 2002. Reduced fungicide applications and host resistance for managing three diseases in pumpkin grown on a no-till cover crop. Plant Dis. 86:1134-1141.

Two recent changes in Maryland pumpkin production are (i) planting no-till into a cover crop with soil surface residue (70\% of acreage) and (ii) adoption of cultivars with moderate resistance to powdery mildew. Pumpkin cultivar resistance to powdery mildew, planting method (notill cover crop or conventional tillage bare ground), and fungicide schedules were examined for development of powdery mildew (caused primarily by Podosphaera xanthii), Plectosporium blight (Plectosporium tabacinum), and black rot (Didymella bryoniae), and pumpkin yield and quality. Fungicide application intervals were (i) nontreated, (ii) 7 days, (iii) 14 days, or (iv) 7 days early and 14 days late season. Pumpkin grown no-till on hairy vetch and hairy vetch plus rye cover crops had an average 36\% less Plectosporium blight and 50\% less black rot than those grown conventional tillage on bare ground. Powdery mildew was less severe on cv. Magic Lantern, which is moderately resistant to this disease, than on susceptible cv. Wizard. Regression equations to describe the impact of disease and treatment on pumpkin fruit number, weight, and peduncle quality (healthy, intact peduncles) were developed using three-stage least squares procedure. Powdery mildew caused the greatest reduction on fruit number, weight, and peduncle quality compared with other diseases. Plectosporium blight reduced fruit number in 1999 and 2000 , and fruit weight and peduncle quality in 2000 . Hairy vetch and hairy vetch plus rye cover crops resulted in greater fruit number (1,033 and 858 more marketable fruit/ha, respectively) than bare ground in 2000. Powdery mildew resistance (Magic Lantern) combined with pumpkin production on a cover crop resulted in lower levels of powdery mildew (average areas under the disease progress curve 1,474 versus 2,379), Plectosporium blight (average 5 versus $16 \%$ severity), and black rot (average 153 versus 217 symptomatic fruit/ha) compared with conventional production (Wizard on bare ground). A reduced fungicide schedule resulted in acceptable disease management, yield, and peduncle quality of Magic Lantern grown on a cover crop; Magic Lantern grown on a cover crop and sprayed every 14 days yielded the same as or more than Wizard grown on bare ground and sprayed weekly.
\end{abstract}

Additional keywords: fruit rot, handle quality, IPM

Several diseases of pumpkin (Cucurbita pepo L.) cause large losses to yield and crop quality in the eastern United States $(5,6,9,13-16,18,34)$. Powdery mildew is caused primarily by Podosphaera xanthii (Castag.) U. Braun \& Shish. comb. nov. in Maryland, where it is the most prevalent foliar disease (14). Plectosporium blight, previously called Microdochium blight and caused by Plectosporium tabacinum (Van Beyma) Arx (syn. Fusarium tabacinum (Van Beyma) W. Gams), causes spindleshaped lesions on the petioles, stems, peduncles, and fruit of pumpkin (6). It was first identified in Tennessee in 1988; since that time it has been observed throughout the eastern United States (14,34). Fruit

Corresponding author: K. L. Everts

E-mail: ke35@umail.umd.edu

Accepted for publication 23 May 2002.

Publication no. D-2002-0814-02R

(C) 2002 The American Phytopathological Society rots, including black rot caused by Didymella bryoniae (Auersw.) Rehm, Fusarium rot caused by several Fusarium spp., Phytophthora fruit rot caused by Phytophthora capsici Leonian, anthracnose caused by Colletotrichum orbiculare (Berk. \& Mont.) Arx, and southern blight caused by Sclerotium rolfsii Sacc., cause additional losses $(9,15,16)$.

Management of these diseases of pumpkin with fungicides significantly increases marketable yield and quality $(21,31)$. However, fungicide applications (up to eight or more in the most intensively managed pumpkin fields) increase production costs. Benomyl, triadimefon, or myclobutanil, all systemic fungicides, have been necessary for optimum suppression of powdery mildew on the abaxial surfaces of leaves (23). Although these fungicides control powdery mildew, they may be less effective on other diseases of pumpkin and often must be combined with broad-spectrum fungicides to manage diseases such as Plectosporium blight and black rot (11). Quinol-oxidizing inhibitor (QoI) fungicides, such as azox- ystrobin (Quadris; Syngenta Crop Protection, Inc., Greensboro, NC), have activity against several diseases and can be applied alone for broad-spectrum control. However, QoI use is limited due to concerns about resistance development. For example, the azoxystrobin cucurbit label restricts the number of sprays per season and recommends applying a fungicide with a different mode of action between each azoxystrobin application.

Winter annual cover crops, spring killed for soil surface residue, and planting notillage seeded pumpkin have been adopted in the mid-Atlantic region due to erosion and nutrient pollution concerns about runoff. In Maryland, approximately $70 \%$ of pumpkin acreage is planted no-till into a killed cover crop. Cover crops with notillage have reduced diseases in tomato (Lycopersicon esculentum Mill.), pepper (Capsicum annuum L.), and strawberry (Fragaria $\times$ ananassa Duch.) $(1,20,30,32)$.

Reduced disease in no-till cover crop systems has been attributed to an inhibition of pathogen dispersal, or alteration in the microclimate that made it less favorable to disease development $(29,32,33)$. Spread of $P$. capsici (causal agent of Phytophthora blight) on pepper was suppressed with a no-till planting into a wheat cover crop compared with bare soil (32). Reduction of disease on strawberry caused by Phytophthora spp. resulted from an interruption of pathogen dispersal (20). Splash dispersal and subsequent development of anthracnose (Colletotrichum acuatum) on strawberry was reduced with a cover crop compared with either bare soil or plastic mulch (30). However, the effect of cover crop is not always beneficial. Tomatoes grown on a zone-till rye cover crop, a reduced tillage system, had more early blight (Alternaria solani Sorauer) in one year and less in another (19).

Several new pumpkin cultivars are moderately resistant (MR) to powdery mildew. Early-season disease progress in these cultivars is slower than in susceptible (S) cultivars; however, yield loss results unless fungicides are applied (24). It is unclear how resistance affects the need for fungicide sprays. Utilizing fungicides or schedules that are not sufficiently effective on susceptible cultivars may give commercially acceptable control on resistant cultivars. For example, fungicides that are acceptable in certified organic operations were ineffective in reducing either pow- 
dery mildew on the lower leaf surface or defoliation in susceptible cultivars. These fungicides did reduce defoliation in a moderately resistant cultivar; however, disease mercial standard (susceptible cultivar treated with conventional fungicides). Pumpkin is susceptible to multiple pathogens; therefore, use of fungicides with moderate efficacy or increasing spray intervals on cultivars resistant only to powdery mildew likely will result in increased pressure from other diseases. However, increased spray intervals may give acceptable control in a production system that combines a no-till cover crop and cultivars with a moderate level of powdery mildew host resistance.

This study was conducted to examine development of powdery mildew, Plectosporium blight, and black rot, along with pumpkin yield and quality in powdery mildew-resistant and -susceptible cultivars that received four fungicide schedules and were grown on bare ground or a cover crop. Preliminary reports of this work have been published $(10,12,13)$.

\section{MATERIALS AND METHODS}

Plot establishment. The experiments were conducted on a Norfolk loamy sand soil at the University of Maryland Lower Eastern Shore Research and Education Center (Salisbury, MD) in 1998, 1999, and 2000. Plots consisted of two rows $6.4 \mathrm{~m}$ long spaced $1.8 \mathrm{~m}$ apart. Two-week-old plants were transplanted on 18 June 1998, 16 June 1999, and 20 June 2000. Plants were $0.9 \mathrm{~m}$ apart within the row.

A split-plot design with four replications was used for all experiments and the main plot was no-tillage cover crop or conventional tillage bare ground. The cover crop was hairy vetch (HV; Vicia villosa Roth) in 1998 and 2000 and a combination of HV + rye (Secale cereale L.) in 1999 and 2000. Subplots were a factorial design of two cultivars, 'Magic Lantern', formerly HMX 5683, which is MR to powdery mildew, or was significantly higher than on the com-

'Wizard', which is $\mathrm{S}$ to powdery mildew (Harris Moran Seed Co., Modesto, CA), and four fungicide schedules. Fungicides were applied weekly, every 14 days, every 7 days early in the season and every 14 days late in the season, or were not applied (Table 1). HV was planted 5 October 1997 and 6 October 1999 at $44.8 \mathrm{~kg} / \mathrm{ha}$. HV $(22.4 \mathrm{~kg} / \mathrm{ha})$ plus rye $(33.6 \mathrm{~kg} / \mathrm{ha})$ were planted 1 October 1998 and 6 October 1999. The HV seed was inoculated with a commercial formulation of Rhizobium spp. prior to planting. $\mathrm{HV}$ and $\mathrm{HV}+$ rye were killed with paraquat (Gramoxone Extra 2.5L, $0.5 \mathrm{~kg}$ a.i./ha) on 27 May 1998, 21 May and 10 June 1999, and 19 May 2000. On 18 May 2000, cover crop plots were cultipacked. Bare ground plots had no HV or $\mathrm{HV}+$ rye residue and were chisel plowed and disked prior to planting.

Fertilizer was applied to the bare ground plots and incorporated $(16 \mathrm{~N}-0 \mathrm{P}-16 \mathrm{~K}$ at 560 $\mathrm{kg} / \mathrm{ha}$ on 11 June $1998 ; 34 \mathrm{~N}-0 \mathrm{P}-0 \mathrm{~K}$ at 168 $\mathrm{kg} / \mathrm{ha}$ and $0 \mathrm{~N}-0 \mathrm{P}-58 \mathrm{~K}$ at $187 \mathrm{~kg} / \mathrm{ha}$ on 10 June 1999; and 34N-0P-0K at $168 \mathrm{~kg} / \mathrm{ha}$ and $0 \mathrm{~N}-0 \mathrm{P}-58 \mathrm{~K}+\mathrm{B}$ at $187 \mathrm{~kg} / \mathrm{ha}$ on $13 \mathrm{June}$ 2000). Cover crop plots received fertilizer (0N-0P-58K at $187 \mathrm{~kg} / \mathrm{ha})$ on 10 June 1999. Topdress fertilizer was applied to all plots on 6 July $1998(15 \mathrm{~N}-3 \mathrm{P}-13 \mathrm{~K}$ at 224 $\mathrm{kg} / \mathrm{ha}$ ) and on 28 June 1999 (34N-0P-0K at $168 \mathrm{~kg} / \mathrm{ha}$ ). Due to poor growth, cover crop plots received an additional fertilizer application (34N-0P-0K at $168 \mathrm{~kg} / \mathrm{ha}$ ) on 16 July 1999. All plots were topdress fertilized on 10 July 2000 (bare ground and HV + rye with $34 \mathrm{~N}-0 \mathrm{P}-0 \mathrm{~K}$ at $168 \mathrm{~kg} / \mathrm{ha}$; and $\mathrm{HV}$ with $34 \mathrm{~N}-0 \mathrm{P}-0 \mathrm{~K}$ at $112 \mathrm{~kg} / \mathrm{ha}$ ).

Grasses were managed with sethoxydim (Poast $1.5 \mathrm{~L}$ at $0.31 \mathrm{~kg}$ a.i./ha) applied to all plots on 13 June 1998 and 10 July 2000. Clomazone (Command 4EC at $0.21 \mathrm{~kg}$ a.i./ha) and bensulide (Prefar $4 \mathrm{E}$ at $4.48 \mathrm{~kg}$ a.i./ha) also were applied for weed control on 19 June 2000. Bare ground plots were cultivated on 25 June 1998. Squash bugs (Anasa tristis De Geer) were controlled with esfenvalerate (Asana XL 0.66L at $0.05 \mathrm{~kg}$ a.i./ha) applied on 6 June 2000.

Table 1. Schedule of fungicide applications to pumpkins grown on a cover crop or bare ground in 1998, 1999, and 2000

\begin{tabular}{|c|c|c|c|}
\hline \multirow[b]{2}{*}{ Year } & \multicolumn{3}{|c|}{ Fungicide application schedule ${ }^{a}$} \\
\hline & Weekly & 7 then 14 days & 14 days \\
\hline 1998 & M-A-M-A-C-A-C-A & M-A-M-A- -C- -A & M- -A- -C- -A \\
\hline 1999 & M-A-C-A-C-A-C-A & M-A-C- - A- -C & M- -A- -C- -A \\
\hline 2000 & M-A-M-A-C $-\mathrm{C}-\mathrm{C}^{\mathrm{b}}-\mathrm{A}$ & M-A-M-A- - $C^{b}--A^{b}$ & M- $-A--C^{b}--A^{b}$ \\
\hline
\end{tabular}

${ }^{a}$ Fungicides used were $\mathrm{M}=$ mancozeb (Dithane $75 \mathrm{DF}, 1.68 \mathrm{~kg}$ a.i./ha) in 1998 and 1999 or maneb (Maneb $75 \mathrm{DF}, 1.68 \mathrm{~kg}$ a.i./ha) in 2000 plus myclobutanil (Nova $40 \mathrm{~W}, 0.07 \mathrm{~kg}$ a.i./ha); $\mathrm{A}=$ azoxystrobin (Quadris 2.08F, $0.27 \mathrm{~kg}$ a.i./ha); and C = chlorothalonil (Bravo Weather Stik 6L, $1.65 \mathrm{~kg}$ a.i./ha in 1998 and Bravo Ultrex 82.5 WDG, $2.48 \mathrm{~kg}$ a.i./ha in 1999 and $1.65 \mathrm{~kg}$ a.i./ha in 2000); "" = 7-day interval; and " - ." = 14-day interval between applications. First application of fungicides was begun when threshold level of one powdery mildew lesion on 45 crown leaves (older quarter of the canopy) was observed on 22 July 1998, 6 August 1999, and 3 August 2000. Mancozeb is not currently registered for use on pumpkin. Mefenoxam formulated as Ridomil Gold EC is not labeled for foliar applications although formulations of mefenoxam that include chlorothalonil or copper (Ridomil Gold Bravo and Ridomil Gold Copper) are labeled. All other fungicides are currently registered for use on pumpkin.

${ }^{\mathrm{b}}$ Mefenoxam (Ridomil Gold EC 4L, $0.10 \mathrm{~kg}$ a.i./ha) also was applied to control downy mildew.
Melon aphids (Aphis gossypii Glover) were controlled with imidacloprid (Provado $1.6 \mathrm{~F}$ at $0.05 \mathrm{~kg}$ a.i./ha) on 21 July 2000.

Leaves were examined weekly for the presence of powdery mildew. After the threshold level (23) of one powdery mildew lesion on 45 crown leaves (older quarter of the canopy) was observed, fungicide applications were begun on 22 July and continued weekly through 11 September 1998, 6 August through 21 September 1999, and 3 August through 20 September 2000. Plots sprayed weekly received eight fungicide applications (Table 1). Plots sprayed at 7- and then 14-day intervals received six fungicide applications in 1998 and 2000 and five in 1999. Plots sprayed every 14 days received four fungicide applications. Fungicides were applied with a tractor-mounted sprayer equipped with four Teejet XR8005 spray tips that delivered 421 liters/ha at 45 psi.

1998. Powdery mildew was evaluated on 9 July, 29 July, 10 August, 17 August, 27 August, 3 September, and 14 September. The percentage of the abaxial and adaxial leaf surfaces that had sporulating powdery mildew lesions was estimated on 10 leaves distributed throughout the canopy ( 3 leaves from the upper third, 4 leaves from the middle third, and 3 leaves from the lower third) and the average percentage of the 20 leaf surfaces was calculated. Plectosporium blight severity on two plants each in three locations in the plot (percent of vine, petioles, and leaf surfaces with symptoms) was rated on 14 September. Mature, asymptomatic fruit (marketable fruit) were harvested on 16 September and individually weighed. Fruit showing symptoms or signs of rot in the field were counted and the cause of rot determined visually; tissue from fruit with representative symptoms was surface disinfested and placed on potato dextrose agar to confirm the diagnosis. Five asymptomatic fruit from each plot were placed in storage (on wooden pallets in a nonheated shed) and evaluated over a 1-month period for presence and cause of fruit rot. (Locally grown pumpkin may be subjected to similar conditions prior to wholesale or retail sale.) The proportion of fruit that developed black rot in storage was multiplied by the number of asymptomatic fruit that were harvested to calculate storage black rot (number of infected fruit/plot). Number of fruit/ha that developed black rot in the field or in storage was calculated.

1999. Methods used in 1998 were modified as follows. Powdery mildew severity was evaluated on 13 August, 19 August, and 2 September. Plectosporium blight severity on vines, petioles, and leaf surfaces was rated on 24 September. Fruit showing symptoms or signs of rot in the field were counted on 1 October and the cause of the rot was determined. Mature, asymptomatic fruit (marketable fruit) were harvested and weighed on 2 October. Pe- 
duncle quality was assessed as the number out of 10 random fruit that had diseased peduncles (peduncles missing or that could not bear the pumpkin's weight). Five asymptomatic fruit from each replicated plot were placed in storage and evaluated after 3 weeks for presence and cause of rot.

2000. Methods used in 1999 were modified as follows. Powdery mildew severity was evaluated on 9 August, 24 August, and 7 September. Plectosporium blight severity on vines, petioles, and leaf surfaces was evaluated on 7 September. Downy mildew was observed in early September and mefenoxam was applied for control (Table 1). However, weather was not conducive to downy mildew development and severity did not increase in sprayed or nonsprayed plots. On 28 September, all mature, asymptomatic fruit (marketable fruit) were harvested and weighed. Peduncle quality and fruit Plectosporium blight incidence (number of fruit with lesions) were evaluated on 10 randomly selected fruit in each plot; and rotting fruit were counted and the cause of rot determined.

Data analyses. The area under the powdery mildew curve (AUPMC) was calculated for each plot using the standard iterative process (35). Analyses of variance were performed on the AUPMC; Plectosporium blight severity on vines, petioles, and leaf surfaces; Plectosporium blight incidence on fruit; number of fruit/ha with black rot; number of marketable fruit/ha at harvest; fruit weight; and peduncle quality using general linear model (GLM) procedure (SAS Institute, Cary, NC). Structural (regression) equations were developed using general least squares analysis performed for a system of equations (SYSLIN procedure, SAS Institute; 17). Variables were standardized to a mean of zero and standard deviation of one prior to performing SYSLIN. Covariance was estimated for variables and was used to produce regression analysis of the same equations (17). In the models developed, number of fruit/ha, fruit weight, peduncle quality, AUPMC, Plectosporium blight, and black rot were defined as endogenous variables (response variables) whose values were determined, in part, by other variables in the system. Replicates, cultivars, cover crop, and fungicide schedule were exogenous variables that may affect endogenous variables but that have values determined outside the system (17). Number of fruit/ha, fruit weight, and peduncle quality were modeled by initially regressing on AUPMC, Plectosporium blight, black rot, cover crops, and cultivars. Variables other than replicate were individually dropped from the model until all remaining variables were significant $(P<0.05)$ and the $F$ test for the model was significant $(P<0.01)$. All data analyses were performed with the Statistical Analysis System (SAS version 8.0, SAS Institute). Fisher's protected least signifi- cant difference (LSD) was used to compare treatments $(P=0.05)$

\section{RESULTS}

Cover crop, cultivar, and fungicide schedule main effects are presented in Table 2. Main effects are discussed where no interactions occurred or where interactions resulted in small differences in magnitude instead of rank. A planned comparison was made between the conventional treatment (Wizard grown on bare ground with fungicides applied every 7 days) and treatments that received fewer fungicide applications (Table 3). Where interactions occurred because of large differences in magnitude or in rank, they are discussed in relation to the planned comparison.

Powdery mildew. Powdery mildew severity on nonsprayed Wizard grown on bare ground was higher earlier in the season in 1998 ( $72 \%$ by 10 August) and 1999 (68\% by 13 August) compared with 2000 ( $30 \%$ on 9 August). Maximum severity of powdery mildew on nonsprayed Wizard and Magic Lantern on bare ground was 88 and $69 \%$ in 1998,81 and $50 \%$ in 1999 , and 83 and $82 \%$ in 2000, respectively. Powdery mildew severity appeared to decline late in the season; however, this was an artifact caused by extensive defoliation of mature infected leaves, which shifted plants to predominantly newly emerged leaves with less infection than older leaves. The AUPMC was lower in pumpkin grown on a cover crop in 1998 and 1999 than on bare ground (Table 2). However, in 2000, cover crop did not impact AUPMC. There was a significant interaction between cover crop, cultivar, and fungicide schedule on AUPMC in 1998 and 1999; Magic Lantern (MR to powdery mildew) on bare ground or cover crop sprayed on a 7 and then 14day schedule, or a 14-day schedule, had a lower AUPMC than the conventional treatment (Wizard, $S$ to powdery mildew, on bare ground sprayed on a 7-day schedule) in both years (Table 3 ). This difference was significant for all four comparisons in 1998 and one comparison in 1999. Magic Lantern sustained significantly less powdery mildew (AUPMC) than Wizard in all years (Tables 2 and 3).

Plectosporium blight. Pumpkin vines, petioles, and leaf surfaces had significantly less Plectosporium blight symptoms on a cover crop than on bare ground in 1999 and 2000 (Table 2). Plectosporium blight severity was high in nonsprayed plots of both Magic Lantern and Wizard on bare ground and in Wizard on a cover crop in 1999; however, nonsprayed Magic Lantern on a cover crop was significantly less severely affected by Plectosporium blight (Table 3). Plectosporium blight was less severe in plots treated with fungicides than in nonsprayed plots in 1999 and 2000 (Table 2). No differences in 7-day, 7- and then 14-day, or the 14-day schedule of treatments occurred, except that Magic Lantern on bare ground sprayed every 14 days had a level of Plectosporium blight similar to nonsprayed plots in 2000 and more severe Plectosporium blight in 2000 than plots sprayed weekly or every 7 and then 14 days (Table 3).

No Plectosporium blight symptoms were observed on fruit in 1998 and 1999. In 2000, when Plectosporium blight symptoms were widespread on fruit, there was no significant difference in incidence of fruit with symptoms in cover crop versus bare ground treatment areas (data not shown). Fungicides reduced the number of fruit with Plectosporium blight symptoms. The number of fruit with Plectosporium blight symptoms combined for both cultivars in nonsprayed plots was 176/ha, whereas fungicide application intervals of 7,14 , or 7 and then 14 days had 57,46 , and 63 symptomatic fruit/ha, respectively $(\mathrm{LSD}=71)$.

Black rot. Less black rot developed on pumpkin grown on HV than on bare ground in $1998(P>0.05)$ and $2000(P>$ 0.10 ) (Table 2). In 1999, the level of black rot was low and the overall model was not significant $(P=0.3741)$. Wizard had significantly fewer fruit with black rot in 1998 than did Magic Lantern (Table 2). In 2000 , there was a significant interaction between cultivar and cover crop; Wizard had significantly fewer fruit with black rot on bare ground compared with Magic Lantern, whereas both cultivars had low levels of black rot in $\mathrm{HV}+$ rye plots, and black rot was not observed in HV plots (Table 3). Black rot severity in 1998 decreased as spray frequency increased from none to weekly applications (Table 2).

Yield and quality. Pumpkin grown on a cover crop yielded more marketable fruit than bare ground pumpkin in 1999 and 2000 (Table 2). Pumpkin grown on a cover crop sprayed on a 14-day schedule had as many fruit $(3,688$ fruit/ha) as pumpkin on cover crop sprayed on a 7- and then 14-day schedule $(3,517$ fruit/ha) or a 7-day schedule $(3,893$ fruit/ha, LSD = 878). However, when pumpkin was grown on bare ground and sprayed on a 14-day schedule, there were significantly fewer marketable fruit ( 2,783 fruit/ha) than when fungicides were sprayed on a 7- and then 14-day schedule $(3,893$ fruit/ha) or a 7 -day schedule $(3,688$ fruit/ha, LSD $=878$ ). There were no differences in fruit number due to cultivar in 1998 or 2000 (Table 2). However, in 1999, significantly more marketable fruit were produced by cultivar Wizard (Table 2).

Fungicide application increased marketable fruit in all years (Table 2). In general, number of fruit increased with number of fungicide applications. This increase was not significant in 1998; whereas, in 1999 and 2000, plots sprayed every 7 and then 14 days or every 7 days had more fruit than plots sprayed on a 14-day schedule (Table 2 ). For both cultivars and ground covers in all years, there was no significant differ- 
ence between the number of fruit in plots sprayed every 7 and then 14 days and the plots sprayed weekly (Table 3). In 1999, fungicide applications at 7- then 14-day intervals increased the number of marketable fruit of Wizard on bare ground compared with 14-day application intervals; however, more fruit were produced on the cover crop where fruit number was unaffected by fungicides applied every 7 then 14 days or every 7 days compared with plots sprayed on a 14-day schedule (Table 3).

Fruit weight $(\mathrm{kg})$ was affected by cover crop in 2000 when pumpkin fruit grown on $\mathrm{HV}$ or $\mathrm{HV}+$ rye were larger than fruit grown on bare ground (Table 2). Pumpkin fruit from plots sprayed with fungicides were larger than fruit from nonsprayed plots in 1998 and 1999 (Table 2). In 1998, an interaction between cultivar and fungi- cide schedule resulted in small differences in magnitude rather than rank, such that application of fungicides to Wizard increased fruit weight over nonsprayed plots; however, fruit weight did not differ significantly where fungicides were applied. The trend was similar but the difference between sprayed and nonsprayed plots was not significant for Magic Lantern (Table 3 ). In cv. Wizard in 2000, mean fruit weight averaged over all ground cover treatments was greater in plots sprayed every 7 and then 14 days $(8.9 \mathrm{~kg}$ ) and every 7 days $(8.7 \mathrm{~kg})$ than in nonsprayed plots $(6.4 \mathrm{~kg}, \mathrm{LSD}=2.3)$.

Peduncle quality was assessed in 1999 and 2000. There was no difference in peduncle quality between bare ground and $\mathrm{HV}+$ rye in 1999 (Table 2). In 2000, a higher percentage of pumpkin grown on a cover crop compared with bare ground had healthy, intact peduncles (Tables 2). Magic Lantern had better peduncle quality than Wizard (Table 2). Fungicide applications increased the percentage of pumpkin with healthy intact peduncles compared with nonsprayed plots. In 1999, peduncle quality was similar for Magic Lantern sprayed every 7,7 and then 14 , or 14 days; however, peduncle quality was better for Wizard sprayed every 7 days compared with 14 days (Table 3).

Powdery mildew had the greatest negative impact on yield based on the threestage least squares procedure. Powdery mildew reduced the number of fruit/ha in all three years and contributed the largest reduction of the variables measured in each year (Table 4). Plectosporium blight was excluded in the 1998 three-stage least squares regression because the analyses of variance model was not significant. In

Table 2. Main effect means of area under the powdery mildew progress curve (AUPMC), Plectosporium blight severity, black rot incidence, yield, and peduncle quality of two pumpkin cultivars grown on bare ground or a cover crop and treated with three fungicide schedules or nonsprayed

\begin{tabular}{|c|c|c|c|c|c|c|}
\hline Year, treatment ${ }^{\mathbf{a}}$ & $\mathbf{A U P M C}^{\mathbf{b}}$ & $\begin{array}{l}\text { Plectosporium } \\
\text { blight }(\%)^{\mathrm{c}}\end{array}$ & $\begin{array}{l}\text { Black rot } \\
\text { (no./ha) })^{\mathbf{d}}\end{array}$ & $\begin{array}{l}\text { No. marketable } \\
\text { fruit/ha }\end{array}$ & $\begin{array}{l}\text { Fruit weight (kg) } \\
\qquad(\bar{x})^{\mathrm{e}}\end{array}$ & $\begin{array}{l}\text { Healthy, intact } \\
\text { peduncles }(\%)^{\mathrm{f}}\end{array}$ \\
\hline \multicolumn{7}{|l|}{1998} \\
\hline Bare ground & $1,321.7$ & 2.3 & 488.6 & $2,815.6$ & 12.0 & ND \\
\hline Hairy vetch & $1,195.9$ & 2.9 & 108.6 & $2,528.0$ & 12.0 & ND \\
\hline Fisher's LSD $(P=0.05)$ & 62.4 & 0.7 & 141.1 & 342.3 & 0.9 & ND \\
\hline Magic Lantern & 695.0 & 2.1 & 464.3 & $2,710.3$ & 13.8 & ND \\
\hline Wizard & $1,822.6$ & 3.1 & 132.9 & $2,633.3$ & 10.2 & ND \\
\hline Fisher's LSD $(P=0.05)$ & 75.3 & 1.3 & 190.6 & 198.8 & 0.5 & ND \\
\hline No fungicide & $2,749.8$ & 4.9 & 581.8 & $2,074.2$ & 10.6 & ND \\
\hline 14-day & $1,227.4$ & 2.4 & 354.9 & $2,835.9$ & 12.2 & ND \\
\hline 7- then 14-day & 643.4 & 1.5 & 158.8 & $2,892.6$ & 12.5 & ND \\
\hline Weekly & 414.5 & 1.6 & 98.9 & $2,884.5$ & 12.6 & ND \\
\hline Fisher's LSD $(P=0.05)$ & 106.5 & $1.8^{\mathrm{g}}$ & 269.5 & 281.1 & 0.6 & ND \\
\hline \multicolumn{7}{|l|}{1999} \\
\hline Bare ground & 498.7 & 9.5 & 67.5 & $2,949.7$ & 11.7 & 59.8 \\
\hline Hairy vetch + rye & 427.6 & 4.3 & 103.3 & $3,321.1$ & 11.6 & 65.0 \\
\hline Fisher's LSD $(P=0.05)$ & 66.3 & 4.6 & 255.9 & 319.4 & 1.1 & 16.2 \\
\hline Magic Lantern & 278.2 & 6.9 & 65.7 & $2,924.1$ & 13.3 & 71.4 \\
\hline Wizard & 648.1 & 6.9 & 105.0 & $3,346.7$ & 10.0 & 53.8 \\
\hline Fisher's LSD $(P=0.05)$ & 46.3 & 1.9 & 144.1 & 312.1 & 0.6 & 6.8 \\
\hline No fungicide & $1,213.3$ & 14.8 & 150.3 & $1,810.0$ & 10.6 & 28.2 \\
\hline 14-day & 388.8 & 5.8 & 42.7 & $3,235.7$ & 11.6 & 62.6 \\
\hline 7- then 14-day & 142.8 & 4.3 & 129.8 & $3,705.3$ & 12.0 & 73.0 \\
\hline Weekly & 107.7 & 2.7 & 150.3 & $3,790.7$ & 12.4 & 83.8 \\
\hline Fisher's LSD $(P=0.05)$ & 65.5 & 2.7 & 203.7 & 441.4 & 0.8 & 9.5 \\
\hline \multicolumn{7}{|l|}{2000} \\
\hline Bare ground & 840.5 & 10.1 & 55.5 & $2,057.5$ & 8.2 & 68.3 \\
\hline Hairy vetch & 781.9 & 4.6 & 0.0 & $3,090.6$ & 10.2 & 86.3 \\
\hline Hairy vetch + rye & 832.3 & 3.8 & 12.8 & $2,915.6$ & 10.3 & 84.7 \\
\hline Fisher's LSD $(P=0.05)$ & 77.3 & 4.2 & 53.3 & 433.2 & 1.7 & 5.6 \\
\hline Magic Lantern & 680.0 & 4.9 & 34.2 & $2,757.6$ & 11.3 & 84.9 \\
\hline Wizard & 956.5 & 7.4 & 11.4 & $2,618.2$ & 7.9 & 74.6 \\
\hline Fisher's LSD $(P=0.05)$ & 58.8 & 3.1 & 27.2 & 183.2 & 0.5 & 4.1 \\
\hline No fungicide & $1,826.2$ & 14.4 & 34.2 & $1,895.3$ & 8.7 & 37.5 \\
\hline 14-day & 727.8 & 6.3 & 11.4 & $2,766.2$ & 9.3 & 92.7 \\
\hline 7- then 14-day & 410.1 & 1.7 & 39.8 & $3,028.0$ & 10.3 & 92.0 \\
\hline Weekly & 308.8 & 2.3 & 5.7 & $3,062.1$ & 10.1 & 96.9 \\
\hline Fisher's LSD $(P=0.05)$ & 83.1 & 4.5 & 38.5 & 259.1 & 0.7 & 5.8 \\
\hline
\end{tabular}

a $\mathrm{LSD}=$ least significant difference.

b AUPMC $=\sum_{i}^{n-1}\left[\left(y_{i}+y_{i+1}\right) / 2\right]\left(t_{i+1}-t_{i}\right)$, in which $y_{i}=$ the average percentage of 10 abaxial and adaxial leaf surfaces distributed throughout the canopy (three upper leaves, four middle leaves, and three lower leaves) that had sporulating powdery mildew lesions expressed as the $i$ th observation, $t_{i}+1-t_{i}$ is the number of days after initial observation, and $n=$ number of observations; $n=7,3$, and 3 in 1998, 1999, and 2000, respectively.

${ }^{c}$ Severity of Plectosporium blight was based on the visual assessment of percent of vines, petioles, and leaf surfaces with symptoms on two plants each in three locations in the plot.

$\mathrm{d}$ The number of fruit that developed black rot at harvest was converted to fruit/ha. The proportion of five asymptomatic fruit that developed black rot in storage was multiplied by the number of asymptomatic fruit/ha harvested. These values were combined to calculate total black rot/ha.

e Weight of each fruit was recorded and the mean fruit weight $(\mathrm{kg})$ determined.

${ }^{\mathrm{f}}$ Peduncles intact, firm and able to bear the pumpkins weight. ND $=$ no data.

g Overall $F$ test of treatments was not significant $(P<0.05)$. 
Table 3. Mean of area under the powdery mildew curve (AUPMC), Plectosporium blight severity, black rot incidence, yield, and peduncle quality of two pumpkin cultivars grown on bare ground or a cover crop and treated with three fungicide schedules or nonsprayed

\begin{tabular}{|c|c|c|c|c|c|c|c|}
\hline $\begin{array}{l}\text { Year, } \\
\text { groundcover, cultivar }\end{array}$ & $\begin{array}{l}\text { Fungicide } \\
\text { interval }\end{array}$ & $\mathbf{A U P M C}^{\mathbf{b}}$ & $\begin{array}{l}\text { Plectosporium } \\
\text { blight }(\%)^{\mathrm{c}}\end{array}$ & $\begin{array}{l}\text { Black rot } \\
(\text { no./ha })^{d}\end{array}$ & $\begin{array}{l}\text { No. marketable } \\
\text { fruit/ha }\end{array}$ & $\begin{array}{l}\text { Fruit weight } \\
\qquad(\mathrm{kg})^{\mathrm{e}}\end{array}$ & $\begin{array}{l}\text { Healthy, intact } \\
\text { peduncles }(\%)^{\text {f }}\end{array}$ \\
\hline \multicolumn{8}{|l|}{1998} \\
\hline \multicolumn{8}{|l|}{ Bare ground } \\
\hline \multirow[t]{4}{*}{ Magic Lantern } & No fungicide & $2,266.1$ & 3.0 & $1,063.0$ & $2,528.0$ & 12.5 & ND \\
\hline & 14-day & 403.1 & 2.5 & 926.9 & $3,079.0$ & 13.9 & ND \\
\hline & 7- then 14-day & 225.5 & 1.0 & 531.5 & $2,916.7$ & 14.0 & ND \\
\hline & 7-day & 168.5 & 1.5 & 395.4 & $2,819.7$ & 14.5 & ND \\
\hline \multirow[t]{4}{*}{ Wizard } & No fungicide & $3,646.1$ & 5.3 & 615.8 & $1,847.4$ & 8.6 & ND \\
\hline & 14-day & $2,001.0$ & 2.5 & 376.0 & $2,981.7$ & 10.8 & ND \\
\hline & 7- then 14-day & $1,095.6$ & 1.0 & 0.0 & $3,370.6$ & 10.2 & ND \\
\hline & 7-day & 767.3 & 1.5 & 0.0 & $2,981.7$ & 11.1 & ND \\
\hline \multicolumn{8}{|l|}{ Hairy vetch } \\
\hline \multirow[t]{4}{*}{ Magic Lantern } & No fungicide & $1,686.1$ & 3.5 & 576.9 & $2,528.0$ & 13.6 & ND \\
\hline & 14-day & 419.4 & 2.0 & 116.7 & $2,592.8$ & 13.4 & ND \\
\hline & 7- then 14-day & 246.1 & 2.5 & 103.7 & $2,528.0$ & 14.4 & ND \\
\hline & 7-day & 145.3 & 1.0 & 0.0 & $2,690.0$ & 14.1 & ND \\
\hline \multirow[t]{4}{*}{ Wizard } & No fungicide & $3,401.0$ & 7.8 & 71.3 & $1,393.6$ & 7.9 & ND \\
\hline & 14-day & $2,086.3$ & 2.5 & 0.0 & $2,690.0$ & 10.7 & ND \\
\hline & 7- then 14-day & $1,006.5$ & 1.5 & 0.0 & $2,754.9$ & 11.5 & ND \\
\hline & 7-day & 576.9 & 2.5 & 0.0 & $3,046.5$ & 10.6 & ND \\
\hline $\operatorname{LSD}(P=0.05)$ & $\ldots$ & 195.6 & 3.3 & 521.1 & 616.7 & 1.5 & ND \\
\hline$P$-value & $\ldots$ & 0.093 & 0.83 & 0.75 & 0.58 & 0.21 & ND \\
\hline \multicolumn{8}{|l|}{1999} \\
\hline \multicolumn{8}{|l|}{ Bare ground } \\
\hline \multirow[t]{4}{*}{ Magic Lantern } & No fungicide & 815.6 & 20.5 & 75.1 & $1,434.3$ & 12.6 & 42.2 \\
\hline & 14-day & 202.9 & 8.8 & 0.0 & $2,732.0$ & 13.0 & 75.0 \\
\hline & 7- then 14-day & 95.3 & 6.8 & 0.0 & $3,585.8$ & 14.0 & 67.5 \\
\hline & 7-day & 47.6 & 4.8 & 0.0 & $3,551.6$ & 13.9 & 85.0 \\
\hline \multirow[t]{4}{*}{ Wizard } & No fungicide & $1,571.3$ & 16.8 & 0.0 & $1,434.3$ & 9.5 & 11.5 \\
\hline & 14-day & 692.3 & 10.0 & 0.0 & $2,834.5$ & 10.7 & 47.5 \\
\hline & 7- then 14-day & 333.0 & 5.0 & 0.0 & $4,200.5$ & 9.4 & 70.0 \\
\hline & 7-day & 231.4 & 3.3 & 464.4 & $3,824.8$ & 10.5 & 75.0 \\
\hline \multicolumn{8}{|l|}{ Hairy vetch \& rye } \\
\hline \multirow[t]{4}{*}{ Magic Lantern } & No fungicide & 767.6 & 6.3 & 0.0 & $2,322.2$ & 11.8 & 46.4 \\
\hline & 14-day & 217.1 & 3.8 & 170.8 & $3,176.0$ & 12.9 & 72.9 \\
\hline & 7-then 14-day & 50.6 & 2.5 & 143.4 & $3,244.3$ & 13.9 & 86.9 \\
\hline & 7-day & 28.9 & 1.8 & 136.6 & $3,346.7$ & 14.3 & 87.9 \\
\hline \multirow[t]{4}{*}{ Wizard } & No fungicide & $1,698.8$ & 15.5 & 0.0 & $2,049.0$ & 8.3 & 16.3 \\
\hline & 14-day & 442.9 & 0.5 & 0.0 & $4,200.5$ & 9.9 & 55.0 \\
\hline & 7- then 14-day & 92.2 & 3.0 & 375.7 & $3,790.7$ & 10.6 & 67.5 \\
\hline & 7-day & 123.0 & 1.0 & 0 & $4,439.5$ & 10.9 & 87.5 \\
\hline $\operatorname{LSD}(P=0.05)$ & $\ldots$ & 137.3 & 6.7 & 450.9 & 878.1 & 1.8 & 23.6 \\
\hline$P$-value & $\ldots$ & 0.0086 & 0.020 & 0.1993 & 0.417 & 0.631 & 0.341 \\
\hline 2000 & & & & & & & \\
\hline Bare ground & & & & & & & \\
\hline Magic Lantern & No fungicide & $1,801.1$ & 12.3 & 68.3 & $1,741.7$ & 9.0 & 17.5 \\
\hline & 14-day & 507.1 & 22.6 & 68.3 & $1,912.4$ & 9.1 & 91.3 \\
\hline & 7- then 14-day & 243.7 & 1.8 & 204.9 & $2,561.3$ & 9.3 & 80.5 \\
\hline & 7-day & 190.3 & 3.3 & 34.2 & $2,288.1$ & 9.4 & 96.3 \\
\hline Wizard & No fungicide & $1,920.8$ & 26.3 & 34.2 & $1,127.0$ & 5.8 & 87.5 \\
\hline & 14-day & 876.2 & 6.6 & 0.0 & $2,117.3$ & 7.1 & 81.3 \\
\hline & 7- then 14-day & 652.6 & 2.0 & 34.2 & $2,151.5$ & 8.5 & 82.5 \\
\hline & 7-day & 532.2 & 5.9 & 0.0 & $2,561.3$ & 7.8 & 88.8 \\
\hline Hairy vetch & & & & & & & \\
\hline Magic Lantern & No fungicide & $1,713.6$ & 4.4 & 0.0 & $2,185.6$ & 12.2 & 71.3 \\
\hline & 14-day & 479.1 & 0.6 & 0.0 & $2,971.1$ & 12.1 & 98.8 \\
\hline & 7- then 14-day & 251.7 & 1.9 & 0.0 & $3,654.1$ & 13.0 & 100.0 \\
\hline & 7-day & 163.2 & 1.4 & 0.0 & $3,859.0$ & 12.1 & 100.0 \\
\hline Wizard & No fungicide & $1,873.1$ & 21.8 & 0.0 & $2,014.9$ & 6.5 & 31.3 \\
\hline & 14-day & 898.6 & 4.8 & 0.0 & $3,210.1$ & 7.4 & 92.5 \\
\hline & 7- then 14-day & 496.6 & 0.6 & 0.0 & $3,346.7$ & 8.7 & 96.3 \\
\hline & 7-day & 379.6 & 1.4 & 0.0 & $3,483.3$ & 9.5 & 100.0 \\
\hline & & & & & & (con & d on next page) \\
\hline
\end{tabular}

a LSD $=$ Fisher's least significant difference. $P$ value is for comparison of the three-way interaction (ground cover $\times$ cultivar $\times$ fungicide interval).

b AUPMC $=\sum_{i}^{n-1}\left[\left(y_{i}+y_{i+1}\right) / 2\right]\left(t_{i+1}-t_{i}\right)$, in which $y_{i}=$ the average percentage of 10 abaxial and adaxial leaf surfaces distributed throughout the canopy (three upper leaves, four middle leaves, and three lower leaves) that had sporulating powdery mildew lesions expressed as the $i$ th observation, $t_{i+1}-t_{i}$ is the number of days after initial observation, and $n=$ number of observations; $n=7,3$, and 3 in 1998, 1999, and 2000, respectively.

c Severity of Plectosporium blight was based on the visual assessment of percent of vines, petioles, and leaf surfaces with symptoms on two plants each in three locations in the plot.

${ }^{\mathrm{d}}$ The number of fruit that developed black rot at harvest was converted to fruit/ha. The proportion of five asymptomatic fruit that developed black rot in storage was multiplied by the number of asymptomatic fruit/ha harvested. These values were combined to calculate total black rot/ha.

e Weight of each fruit was recorded and the mean fruit weight $(\mathrm{kg})$ determined.

f Peduncles intact, firm and able to bear the pumpkin's weight. ND = no data. 
Table 3. (continued from preceding page)

\begin{tabular}{|c|c|c|c|c|c|c|c|}
\hline $\begin{array}{l}\text { Year, } \\
\text { groundcover, cultivara }\end{array}$ & $\begin{array}{l}\text { Fungicide } \\
\text { interval }\end{array}$ & AUPMC $^{b}$ & $\begin{array}{l}\text { Plectosporium } \\
\text { blight }(\%)^{\mathrm{c}}\end{array}$ & $\begin{array}{l}\text { Black rot } \\
\text { (no./ha) }^{\mathrm{d}}\end{array}$ & $\begin{array}{l}\text { No. marketable } \\
\text { fruit/ha }\end{array}$ & $\begin{array}{c}\text { Fruit weight } \\
(\mathbf{k g})^{\mathrm{e}}\end{array}$ & $\begin{array}{l}\text { Healthy, intact } \\
\text { peduncles }(\%)^{f}\end{array}$ \\
\hline \multicolumn{8}{|l|}{2000} \\
\hline \multicolumn{8}{|l|}{ Hairy vetch \& rye } \\
\hline \multirow[t]{4}{*}{ Magic Lantern } & No fungicide & $1,727.1$ & 6.8 & 34.2 & $2,322.2$ & 12.2 & 70.0 \\
\hline & 14-day & 648.9 & 2.4 & 0.0 & $3,176.0$ & 11.4 & 98.8 \\
\hline & 7- then 14-day & 267.6 & 1.3 & 0.0 & $3,210.1$ & 12.6 & 97.5 \\
\hline & 7-day & 166.3 & 0.5 & 0.0 & $3,210.1$ & 12.8 & 97.5 \\
\hline \multirow{4}{*}{ Wizard } & No fungicide & $1,921.8$ & 15.0 & 68.3 & $1,981.7$ & 6.9 & 26.3 \\
\hline & 14-day & 957.0 & 0.8 & 0.0 & $3,210.1$ & 8.4 & 93.8 \\
\hline & 7- then 14-day & 548.2 & 2.4 & 0.0 & $3,244.3$ & 9.4 & 95.0 \\
\hline & 7-day & 421.4 & 1.2 & 0.0 & $2,971.1$ & 8.9 & 98.8 \\
\hline $\operatorname{LSD}(P=0.05)$ & $\ldots$ & 205.1 & 11.0 & 102.7 & 732.8 & 2.3 & 14.4 \\
\hline$P$ value & $\ldots$ & 0.87 & 0.31 & 0.73 & 0.60 & 0.63 & 0.044 \\
\hline
\end{tabular}

1999 and 2000, Plectosporium blight reduced marketable fruit number. In 1998, black rot reduced marketable fruit number; however, the magnitude of the reduction was small (Table 4). Black rot was excluded in the 1999 three-stage least squares regressions because the analyses of variance model was not significant. A higher number of marketable fruit/ha was obtained in the $\mathrm{HV}$ and the $\mathrm{HV}+$ rye cover crop in 2000.

Fruit weight also was affected by disease. Increasing powdery mildew severity reduced mean fruit weight in 1998 and 1999. Plectosporium blight and black rot reduced fruit weight in 2000. Magic Lantern had greater mean fruit weight in all years.

Powdery mildew caused the largest reduction in healthy, intact peduncles in both 1999 and 2000 when peduncle quality was measured. Plectosporium blight and black rot reduced peduncle quality only in 2000 .

\section{DISCUSSION}

Producing pumpkin with no-till on a spring-killed cover crop significantly reduced Plectosporium blight severity and the number of fruit/ha affected by black rot compared with conventional tillage and bare ground. Powdery mildew severity on pumpkin on cover crop compared with bare ground also was reduced in 2 of the 3 years of this study. The beneficial effect of cover crop agrees with previous reports of disease reductions in strawberry, tomato, and pepper $(1,19,20,30)$.

Host resistance (cv. Magic Lantern) performed well under high powdery mildew pressure occurring in this study, even in the absence of intensive fungicide sprays. In some crops, resistant cultivars are associated with lower yield. Summer squash with resistance to powdery mildew was less severely infected than the susceptible cultivar it was compared with. However, even when treated with fungicides, the resistant cultivar yielded less than the fungicidetreated susceptible cultivar (26). In this study, however, number of fruit was comparable between Magic Lantern (MR) and Wizard (S).

Optimum disease management programs for commercial vegetable growers combine tactics to manage multiple diseases and reduce the need for frequent fungicide applications. Here a combination of two tactics (production on a no-tillage cover crop in combination with moderate host resistance to powdery mildew) resulted in reduced need for fungicide applications and, at the same time, improved yield and quality. Partial control of powdery mildew achieved with host resistance subsequently influenced the level of control achieved with different fungicide schedules. Control of powdery mildew obtained with Magic Lantern sprayed four times on a 14-day schedule was similar to control obtained with susceptible Wizard sprayed eight times on a 7-day schedule when on bare ground. Magic Lantern on bare ground developed more black rot than Wizard, and a reduction in fungicide applications resulted in an unacceptable high level of black rot. Less black rot developed on Magic Lantern on a cover crop compared with bare ground and the black rot severity on Magic Lantern on a cover crop was similar to severity on Wizard. There was no difference between cultivars in susceptibility to Plectosporium blight; however, the cover crop significantly reduced the disease and affected the necessity of frequent fungicide applications compared with bare ground.

Another reason to use several management practices is to delay development of pathogen resistance to fungicides. Powdery mildew on pumpkin begins to develop between mid-July and early August in Maryland, where the fungus apparently does not overwinter. Cleistothecia rarely are found in the United States and the pathogen is thought to be dispersed northward yearly (28). Selection pressure within one growing season is sufficient to result in large increases in Podosphaera xanthii isolates resistant to benomyl and triadimefon $(25,27)$. A reduction in the frequency of fungicide applications reduces selection pressure both within a growing season and over seasons (7). McGrath et al. (22) demonstrated that, once resistance to benomyl or triadimefon has developed within a $P$. xanthii population, change in fungicide sensitivity within a growing season occurs rapidly (within the first 2 weeks after two applications of triadimefon were applied). In the current study, acceptable control was achieved when the fungicide application intervals were extended to 14 days on an MR cultivar on a cover crop production system. Under a system that combines host resistance, no-till cover crop, and fewer fungicide applications, the two fungicide applications that shift the pathogen population to a high frequency of resistant strains would be completed later in the growing season.

The mechanism by which disease was reduced in a cover crop was not studied for pumpkin. However, diseases were reduced in pepper and tomato grown on a no-till cover crop because pathogen dispersal was reduced (32) or conduciveness of the microclimate was reduced (29). These changes resulted, in part, from the presence of the cover crop residue on the soil surface. Cover crops ( $\mathrm{HV}$ and $\mathrm{HV}+$ rye) formed a barrier between soil and pumpkin fruit; $\mathrm{HV}$ + rye resulted in a thicker and longer-lasting barrier between the fruit and ground than did $\mathrm{HV}$ alone. If this barrier contributed to reduced disease through reduced splash dispersal or alternation of the microclimate, $\mathrm{HV}$ + rye may provide greater reduction in disease than $\mathrm{HV}$ alone. However, disease severity did not differ between the HV and HV + rye cover crops in this study. Improved plant nutrition with cover crops could contribute to disease resistance as suggested by Mills, et. al. compared with bare ground (29). Nutrient content of pumpkin foliage was not measured; however, tomato grown on no-till HV cover crops had increased total $\mathrm{N}$ content $(3,4)$ and lower $\mathrm{P}(29)$ compared with conventional tillage in previous studies in Maryland. Foliar nutrient content influenced powdery mildew in muskmelon where boron-deficient muskmelon had more severe powdery mildew than muskmelon grown in boron-amended soil (8).

No-till cover crop benefits vary from region to region due to changes in climate, soil type, and prevalent diseases. Production of pumpkin on a no-till cover crop has been widely adopted in Maryland because the benefits in reducing soil erosion and nutrient runoff and improving soil health are pronounced. Delays in maturity due to 
Table 4. Three-stage least squares model parameter estimates of the effect of the areas under the powdery mildew progress curve (AUPMC), Plectosporium blight, black rot, and cover crops on fruit number, fruit weight, and peduncle quality of pumpkin in 1998,1999 , and $2000^{\mathrm{a}}$

\begin{tabular}{|c|c|c|c|c|c|c|}
\hline & \multicolumn{2}{|c|}{1998} & \multicolumn{2}{|c|}{1999} & \multicolumn{2}{|c|}{2000} \\
\hline \multicolumn{7}{|l|}{ No. fruit/ha ${ }^{b}$} \\
\hline Intercept & -0.367 & \pm 0.155 & 0.004 & \pm 0.074 & $1.24 \times 10^{-15}$ & \pm 0.056 \\
\hline AUPMC $^{c}$ & -0.906 & \pm 0.145 & -0.510 & \pm 0.148 & -0.430 & \pm 0.078 \\
\hline Plectosporium blight ${ }^{\mathrm{d}}$ & $\ldots$ & $\ldots$ & -0.406 & \pm 0.176 & -0.260 & \pm 0.111 \\
\hline Black rot/ha $\mathrm{e}^{\mathrm{e}}$ & -0.001 & \pm 0.000 & $\ldots$ & $\ldots$ & $\ldots$ & $\ldots$ \\
\hline Cultivar $^{\mathrm{f}}$ & -0.594 & \pm 0.159 & -0.374 & \pm 0.088 & $\ldots$ & $\ldots$ \\
\hline Cover crop $1^{\mathrm{g}}$ & $\ldots$ & $\ldots$ & $\ldots$ & $\ldots$ & 0.391 & \pm 0.077 \\
\hline Cover crop $2^{\mathrm{h}}$ & $\ldots$ & $\ldots$ & $\ldots$ & $\ldots$ & 0.185 & \pm 0.080 \\
\hline Replicate & 0.283 & \pm 0.175 & -0.158 & \pm 0.133 & 0.798 & \pm 0.097 \\
\hline \multicolumn{7}{|l|}{ Mean fruit weight } \\
\hline Intercept & $4.18 \times 10^{-16}$ & \pm 0.053 & -0.011 & \pm 0.069 & $-4.87 \times 10^{-16}$ & \pm 0.082 \\
\hline AUPMC & -0.410 & \pm 0.062 & -0.330 & \pm 0.076 & $\ldots$ & $\ldots$ \\
\hline Plectosporium blight & $\ldots$ & $\ldots$ & $\ldots$ & $\ldots$ & -0.439 & \pm 0.114 \\
\hline Black rot/ha & $\ldots$ & $\ldots$ & $\ldots$ & $\ldots$ & -0.408 & \pm 0.142 \\
\hline Cultivar & 0.587 & \pm 0.061 & 0.638 & \pm 0.073 & 0.658 & \pm 0.070 \\
\hline Replicate & 0.386 & \pm 0.091 & 0.200 & \pm 0.120 & 0.347 & \pm 0.146 \\
\hline \multicolumn{7}{|l|}{ Healthy, intact peduncles } \\
\hline Intercept & $\ldots$ & $\ldots$ & -0.011 & \pm 0.067 & $-3.53 \times 10^{-16}$ & \pm 0.058 \\
\hline AUPMC & $\ldots$ & $\ldots$ & -0.836 & \pm 0.068 & -0.665 & \pm 0.067 \\
\hline Plectosporium blight & $\ldots$ & $\ldots$ & $\ldots$ & $\ldots$ & -0.364 & \pm 0.099 \\
\hline Black rot/ha & $\ldots$ & $\ldots$ & $\ldots$ & $\ldots$ & -0.306 & \pm 0.100 \\
\hline Replicate & $\ldots$ & $\ldots$ & 0.431 & \pm 0.116 & 0.388 & \pm 0.104 \\
\hline
\end{tabular}

a ... indicates that the variable was dropped from the model because it was not significant $(P=0.05)$.

b Number of marketable fruit/ha, mean fruit weight $(\mathrm{kg})$, and peduncle quality (percent of fruit with intact, nondiseased peduncles) were modeled initially by regressing on AUPMC, Plectosporium blight severity (1999 and 2000), number of fruit with black rot/ha (1998 and 2000), cover crops, cultivars, and replicate. Variables other than replicate were individually dropped from the model until all remaining variables were significant $(P<0.05)$ and the $\mathrm{F}$ test for the model was significant $(P<0.01)$. Prior to analyses variables were standardized to a mean of zero and standard deviation of one.

c AUPMC $=\sum_{i}^{n-1}\left[\left(y_{i}+y_{i+1}\right) / 2\right]\left(t_{i+1}-t_{i}\right)$, in which $y_{i}=$ the average percentage of 10 abaxial and adaxial leaf surfaces distributed throughout the canopy (three upper leaves, four middle leaves, and three lower leaves) that had sporulating powdery mildew lesions expressed as the $i$ th observation, $t_{i+1}-t_{i}$ is the number of days after initial observation, and $n=$ number of observations; $n=7,3$, and 3 in 1998, 1999, and 2000, respectively.

${ }^{\mathrm{d}}$ Severity of Plectosporium blight was based on the visual assessment of percent of vines, petioles and leaf surfaces with symptoms on two plants each in three locations in the plot.

e The number of fruit that developed black rot at harvest was converted to fruit/ha. The proportion of five asymptomatic fruit that developed black rot in storage was multiplied by the number of asymptomatic fruit/ha harvested. These values were combined to calculate total black rot/ha.

f Cultivar = Magic Lantern, Wizard.

g Cover crop 1 = hairy vetch - bare ground

${ }^{\mathrm{h}}$ Cover crop 2 = hairy vetch and rye - bare ground.

reduced spring soil temperatures associated with no-till cover crops limits its adoption in some vegetables (2), but not in pumpkin, which is planted in late spring or early summer and marketed in the fall. If growers combine no-till cover crop production with moderately resistant cultivars, the benefits growers have realized from adoption of no-till cover crops can be extended to reduction of fungicide inputs. This will reduce production costs, including labor, minimize fungicide residues on pumpkin fruit, and may assist in delay of resistance development of pathogens to fungicides.

\section{LITERATURE CITED}

1. Abdul-Baki, A. A., Stommel, J. R., Teasdale, J. R., and Goth, R. W. 1995. Effect of hairy vetch and black polyethylene mulches on yield and disease reaction of processing tomatoes. Pages 41-48 in: Proc. 26th Annu. MidAtlantic Veg. Work. Conf. Univ. Del. Newark. C. A. McClurg, ed.

2. Abdul-Baki, A. A., Stommel, J. R., Watada, A. E., Teasdale, J. R., and Morse, R. D. 1996. Hairy Vetch mulch favorably impacts yield of processing tomatoes. HortScience 31:338340.

3. Abdul-Baki, A. A., Teasdale, J. R., and Korcak, R. F. 1997. Nitrogen requirements of fresh-market tomatoes on hairy vetch and black polyethylene mulch. HortScience 32:217-221.

4. Abdul-Baki, A. A., Teasdale, J. R., Korcak, R. F., Chitwood, D. J., and Huettel, R. N. 1996.
Fresh-market tomato production in a lowinput alternative system using cover-crop mulch. HortScience 31:65-69.

5. Alexander, S. A., and Waldenmaier, C. M. 1999. Evaluation of fungicides for control of powdery mildew in pumpkin, 1998. Fungic. Nematic. Tests 54:224.

6. Bost, S. C., and Mullins, C. A. 1992. A blight of cucurbits caused by Microdochium tabacinum. Plant Dis. 76:861.

7. De Waard, M. A., Georgopoulos, S. G., Hollomon, D. W., Ishii, H., Leroux, P., Ragsdale, N. N., and Schwinn, F. J. 1993. Chemical control of plant diseases: problems and prospects. Annu. Rev. Phytopathol. 31:403-421.

8. Eaton, F. M. 1944. Deficiency, toxicity and accumulation of boron in plants. J. Agric. Res. 69:237-277

9. Elmer, W. H. 1996. Fusarium fruit rot of pumpkin in Connecticut. Plant Dis. 80:131135.

10. Everts, K. L. 1999. Integrated pumpkin disease management using a cover crop, host resistance and reduced fungicide application. (Abstr.) Phytopathology 89:S25.

11. Everts, K. L., and Mulrooney, R. P. 1997. Evaluation of fungicide regimes for the control of powdery mildew on cantaloupe, 1996. Fungic. Nematic. Tests 52:104.

12. Everts, K. L., and Shields, P. L. 1999. Evaluation of hairy vetch ground cover and host resistance for reducing fungicide use in pumpkins, 1998. Biol. Cult. Tests Control Plant Dis. 14:177.

13. Everts, K. L., and Shields, P. L. 2000. Evaluation of the effectiveness of ground cover and host resistance in reducing fungicide use in pumpkins, 1999. Biol. Cult. Tests Control
Plant Dis. 15:176-177.

14. Everts, K. L., Shields, P. L., and Armentrout, D. K. 2001. Evaluation of fungicides for control of powdery mildew and Plectosporium blight on pumpkin, 2000. Fungic. Nematic. Tests 56:V68-69.

15. Holmes, G. J., Adams, M. L., Schultheis, J. R., and Stanghellini, M. S., 2000. Susceptibility of pumpkin cultigens to postharvest fruit rot. 1999. Biol. Cult. Tests Control Plant Dis. $15: 183$.

16. Holmes, G. J., Schultheis, J. R., and Stanghellini, M. S., 1999. Susceptibility of pumpkin cultigens to postharvest fruit rot. 1998. Biol. Cult. Tests Control Plant Dis. 14:171.

17. Judge, G. G., Lee, T., and Hill, R. C. 1985. An Introduction to simultaneous linear statistical models. Pages 599-671 in: Introduction to the Theory and Practice of Econometrics. 2nd ed. Wiley, New York.

18. Keinath, A. P., and DuBose, V. B. 1997. Reaction of 32 pumpkin cultivars to foliar fungal diseases and mixed virus infection, 1996. Biol. Cult. Tests Control Plant Dis. 12:164.

19. Louws, F. J., Hausbeck, M. K., Kelly, J. F. and Stephens, C. T. 1996. Impact of reduced fungicide and tillage on foliar blight, fruit rot, and yield of processing tomatoes. Plant Dis. 80:1251-1256.

20. Madden, L. V., and Ellis, M. A. 1990. Effect of ground cover on splash dispersal of Phytophthora cactorum from strawberry fruits. J. Phytopathol. 129:170-174.

21. McClurg, C. A., Rouse, R. J., and Kantzes, J. G. 1992. Evaluation of field performance and post harvest quality of pumpkin. Pages 135-138 in: Proc. 23rd Annu. Mid-Atlantic Veg. Work. Conf. Univ. Del. Newark. P. A. Ferretti, ed. 
22. McGrath, M. T. 1996. Increased resistance to triadimefon and to benomyl in Sphaerotheca fuliginea populations following fungicide usage over one season. Plant Dis. 80:633-639.

23. McGrath, M. T. 1996. Successful management of powdery mildew in pumpkin with disease threshold-based fungicide programs. Plant Dis. 80:910-916.

24. McGrath, M. T. 2001. Alternative fungicides to Bravo evaluated on pumpkin cultivars differing in susceptibility to powdery mildew, 2000. Fungic. Nematic. Tests 56:V77.

25. McGrath, M. T., and Staniszewska, H. 1994. An IPM program for powdery mildew in pumpkin that includes timing of chemical control and fungicide resistance considerations. (Abstr.). Phytopathology 84:545.

26. McGrath, M. T., and Staniszewska, H. 1996. Management of powdery mildew in summer squash with host resistance, disease thresh- old-based fungicide programs, or an integrated program. Plant Dis. 80:1044-1052.

27. McGrath, M. T., Staniszewska, H., Shishkoff, N., and Casella, G. 1996. Fungicide sensitivity of Sphaerotheca fuliginea populations in the United States. Plant Dis. 80:697-703.

28. McGrath, M. T., Staniszewska, H., Shishkoff, N., and Casella, G. 1996. Distribution of mating types of Sphaerotheca fuliginea in the United States. Plant Dis. 80:1098-1102.

29. Mills, D. J., Coffman, C. B., Teasdale, J. R., Everts, K. L., and Anderson, J. D. 2002. Factors associated with foliar disease of staked fresh market tomatoes grown under differing bed strategies. Plant Dis. 86:356-361.

30. Ntahimpera, N., Ellis, M. A., Wilson, L. L., and Madden, L. V. 1998. Effects of a cover crop on splash dispersal of Colletotrichum acutatum conidia. Phytopathology 88:536-543.

31. Reiners, S., and Riggs, D. I. M. 1997. Plant spacing and variety affect pumpkin yield and fruit size, but supplemental nitrogen does not. HortScience 32:1037-1039.

32. Ristaino, J. B., Parra, G., and Campbell, C. L. 1997. Suppression of Phytophthora blight in bell pepper by a no-till wheat cover crop. Phytopathology 87:242-249.

33. Roe, N. E., Stofella, P. J., and Bryan, H. H. 1994. Growth and yield of bell pepper and winter squash grown with organic and living mulches. J. Am. Soc. Hortic. Sci. 119:11931199.

34. Shamiyeh, N. B., Straw, R. A., Mullins, C. A., and Follum, R. A. 1999. Foliar fungicides for control of diseases on pumpkins, 1998. Fungic. Nematic. Tests 54:233-234.

35. Shaner, G., and Finney, R. E. 1977. The effect of nitrogen fertilization on the expression of slow-mildewing resistance in Knox wheat. Phytopathology 67:1051-1056. 